\title{
PENGOLAHAN AIR TANAH BERBASIS TREATMENT RESIN PENUKAR ION, ZEOLIT DAN SINAR UV
}

\author{
Ahmad Setiawan ${ }^{1)}$, Setyo Purwoto ${ }^{1)}$ \\ 1) Progam Studi Teknik Lingkungan, Fakultas Teknik Sipil dan Perencanaan \\ Universitas PGRI Adi Buana (UNIPA) Surabaya \\ Email: ahmadsetiawan078@gmail.com
}

\begin{abstract}
Abstrak
Permasalahan ketersediaan air bersih merupakan masalah yang sering terjadi di daerah pesisir. Hal ini karena air di daerah pesisir tergolong air sadah yang dalam penggunaannya harus dilakukan pengolahan terlebih dahulu. Permasalahan yang diambil pada penelitian ini adalah air tanah yang terdapat di Desa Tambak Cemandi Kecamatan Sedati Kabupaten Sidoarjo yang letaknya berada di pesisir Sidoarjo. Salah satu alternatif yakni dengan menggunakan teknologi pengolahan air menggunakan resin penukar ion, zeolit dan penyinaran UV. Tujuan dari penelitian ini yaitu untuk mengetahui hasil parameter air tanah sebelum dan sesudah ditreatment, mengkaji nilai tingkat efektivitas dan waktu tinggal paling baik dari treatment menggunakan resin penukar ion, zeolit dan sinar UV untuk parameter uji klorida $\left(\mathrm{Cl}^{-}\right)$, kesadahan dan bakteri coliform. Penelitian ini menggunakan reaktor yang terdiri dari tabung FRP 10 inchi sebagai tempat filtrasi zeolit, housing filter anion kation, dan sinar UV. Variasi waktu tinggal yang digunakan yaitu 30 menit dan 60 menit. Hasil treatment menunjukkan kadar klorida dapat diturunkan hingga 2033,1 $\mathrm{mg} / \mathrm{L}$ dengan efisiensi sebesar $45 \%$, kadar kesadahan hingga 1394,2 mg/L dengan efisiensi sebesar 32,7 \%, dan kandungan bakteri coliform hingga 60 MPN/100ml dengan efisiensi sebesar 99,2 \%. Konsentrasi kadar tersebut belum memenuhi baku mutu air bersih PERMENKES $32 / 2017$.
\end{abstract}

Kata Kunci: Bakteri Coliform, Sinar UV, Zeolit, Resin Kation Anion.

\begin{abstract}
The problem of the availability of clean water is a problem that often occurs in coastal areas. This is because the water in the coastal areas is classified as hard water which must be treated first. The problem taken in this study is the groundwater in Tambak Cemandi Village, Sedati Subdistrict, Sidoarjo Regency which is located on the coast of Sidoarjo. One alternative is to use water treatment technology using ion exchange resins, zeolites, and UV irradiation. The purpose of this study is to determine the results of groundwater parameters before and after treatment, assess the value of the level of effectiveness and the best residence time of treatment using an ion exchange resin, zeolite and UV light for the parameters of the chloride test (Cl-), hardness and coliform bacteria. This research uses a reactor consisting of 10-inch FRP tubes for zeolite filtration, anion cation filter housing, and UV light. The residence time variations used are 30 minutes and 60 minutes. The treatment results show that chloride levels can be reduced to $2033.1 \mathrm{mg} / \mathrm{L}$ with an efficiency of 45\%, hardness levels up to $1394.2 \mathrm{mg} / \mathrm{L}$ with an efficiency of $32.7 \%$, and coliform bacteria content up to $60 \mathrm{MPN} / 100 \mathrm{ml}$ with an efficiency of $99,2 \%$. These concentrations do not meet the PERMENKES 32/2017 clean water quality standards.
\end{abstract}

Keywords: Coliform Bacteria, UV Light, Zeolite, Anion Cation Resin. 


\section{PENDAHULUAN}

Meningkatkannya

jumlah pertumbuhan penduduk serta aktifitas manusia di bidang ekonomi, pembangunan dan industri yang tergantung pada setiap daerah akan memberikan dampak kesulitan mendapatkan air bersih untuk keperluan rumah tangga. Penyebab penurunan kualitas air salah satunya adalah tercemarnya air sumur oleh bakteri golongan coliform yang diakibatkan dari kepadatan penduduk, buruknya sistem pembuangan limbah masyarakat, pembuatan wc, septik tank dan sumur resapan yang kurang memenuhi persyaratan dengan baik ditinjau dari kualitas maupun tata letaknya terhadap sumber pencemar. Wilayah dengan septic tank yang banyak merupakan penghasil bakteri fecal coliform yang tinggi (Eukene $e t$ al. 2014).

Pada umumnya air tanah atau air sumur mempunyai tingkat kandungan bakteri coliform yang tinggi. Bakteri Coliform merupakan golongan bakteri yang termasuk ke dalam famili Enterobacteriaceae, hidup disaluran pencernaan manusia dan hewan (Cahyadi dan Winanti, 2014), melaporkan bahwa sampel Perumahan Sedati Permai di wilayah Pabean Sedati Sidoarjo menunjukkan hasil: total koliform berkisar $20 \mathrm{MPN} / 100 \mathrm{~mL}$ sampai 1.600 MPN/100mL, yang berpotensi dapat menggangu kesehatan jika dikonsumsi untuk kebutuhan air minum dan masak. Escherechia coli apabila dikonsumsi terusmenerus dalam jangka panjang akan berdampak pada timbulnya penyakit seperti radang usus, diare, infeksi pada saluran kemih dan saluran empedu (Prayitno, 2009).

Air sadah adalah air yang di dalamnya terlarut garam-garam kalsium dan magnesium, air sadah tidak baik untuk mencuci karena ion-ion $\mathrm{Ca}^{+}$dan $\mathrm{Mg}^{+}$akan berikatan dengan sisa asam karbohidrat pada sabun dan membentuk endapan sehingga sabun tidak berbuih. Penelitian yang dilakukan oleh Nurhayati. (2006), melaporkan bahwa sampel pesisir Sidoarjo Jawa timur Indonesia menunjukkan hasil: kadar klorida sekitar $8580 \mathrm{mg} / \mathrm{L}$ sedang TDS sekitar $19.310 \mathrm{mg} / \mathrm{L}$, dan kesadahan $7560 \mathrm{mg} / \mathrm{L}$ (sebagai $\mathrm{CaCO} 3$ ), dimana kondisi tersebut sangat jauh dari memenuhi kriteria sebagai air bersih. Adanya ion-ion tersebut dalam air sadah dapat mengganggu kesehatan seperti terjadinya endapan kapur pada ginjal atau saluran kencing (Supardi,2009).

Permasalahan yang diambil pada penelitian ini adalah air tanah yang terdapat di Desa Tambak Cemandi Kecamatan Sedati Kabupaten Sidoarjo yang letaknya berada di pesisir Sidoarjo. Dari penelitian pendahuluan yang dilakukan peneliti yaitu pada titik sumur gali (air tanah) warga. Pada titik tersebut didapat nilai kandungan total coliform sebesar $7100 \mathrm{MPN} / 100 \mathrm{ml}$, nilai kadar klorida $\left(\mathrm{Cl}^{-}\right)$sebesar 3694,3 mg/L dan kesadahan sebesar 2071,5 ppm. Sedangkan nilai ambang batas yang diperbolehkan menurut Peraturan Menteri Kesehatan Republik Indonesia Nomor 32 Tahun 2017 untuk keperluan Higiene sanitasi yaitu nilai kandungan bakteri coliform hanya diperbolehkan maksimal sebesar 50 MPN/100ml, kadar $\mathrm{Cl}^{-} 600 \mathrm{mg} / \mathrm{L}$ dan untuk kesadahan $500 \mathrm{mg} / \mathrm{L}$.

Dalam penyediaan air bersih bagi masyarakat, perlu adanya inovasi teknologi terbaru yang efektif dan efisien serta sesuai dengan keadaan masyarakat itu sendiri. Salah satu alternatif yakni dengan menggunakan teknologi pengolahan air menggunakan resin penukar ion, zeolit dan penyinaran UV. Hal ini karena penelitian tentang teknologi pengolahan air payau melalui penukar ion dan filtrasi campuran zeolit aktif dengan karbon aktif menunjukkan bahwa efisiensi penurunan kadar klorida berkisar antara 57-65 \% (Nugroho dan Purwoto,2013). Filter dengan kombinasi media pecahan genteng- zeolit dapat menurunkan $\mathrm{CaCO}_{3}$ efisiensi mencapai $81 \%$ dan bakteri coliform dengan efisiensi mencapai 58\% (Rahmawati dan Nurhayati, 2013). Lampu ultra violet yang dikombinasikan dengan reaktor dapat digunakan untuk menyisihkan bakteri E.coli dengan variasi reaktor diameter $2,5^{\prime \prime}$ mencapai $80 \%$, variasi diameter $3^{\prime \prime}$ mencapai $79 \%$, variasi diameter $4 "$ mencapai $77 \%$ dengan waktu pemaparan 100 menit ( Rakkito dan Surya, 2015).

Pertukaran ion adalah proses dimana satu bentuk ion dalam senyawa dipertukarkan untuk beberapa bentuk, yaitu 
kation ditukar dengan kation dan anion ditukar dengan anion. Pertukaran ion berlangsung secara reversibel dan dapat diregenerasi atau diisi dengan ion-ion yang diinginkan melalui pencucian dengan ionion yang berlebih. Proses pertukaran ion terjadi secara kontinyu sampai resin telah jenuh dengan ion yang ditukarkan. Oleh karena itu, jika resin telah jenuh dengan ion yang dipertukarkan, maka dapat diregenerasi dengan asam atau basa (Ita Ulfin, 2013).

Proses pertukaran ion melibatkan reaksi kimia antara ion dalam fase cair dengan ion dalam fase padat. Ion-ion tertentu dalam larutan lebih mudah diserap oleh pertukaran ion padat, dan karena elektronetralitas harus dipertahankan, penukar ion padat menghilangkan ion dan menukar ion dalam larutan. Dalam proses demineralisasi, maka sebagai contoh; kation $\mathrm{Na}+$ dan anion $\mathrm{Cl}$ - dihilangkan dari air dan ion kehilangan resin padat $\mathrm{H}+$ untuk ditukar dengan ion $\mathrm{Na}+$, dan juga $\mathrm{OH}-$ ditukar dengan $\mathrm{Cl}$ - dari air sehingga kandungan $\mathrm{Na}$ + dan Cl- dalam air berkurang atau hilang (Nurhayati, 2014).

Adsorbsi adalah proses dimana molekul-molekul fluida menyentuh dan melekat pada permukaan padatan. Adsorbsi adalah fenomena fisik yang terjadi saat molekul-molekul gas atau cairan dikontakkan dengan suatu permukaan padatan tersebut. Molekul-molekul pada permukaan zat padat atau zat cair mempunyai gaya dalam keadaan tidak setimbang (unbalance) yang cenderung tertarik ke arah dalam (gaya kohesi>gaya adhesi) (Atmoko RD, 2012).

Zeolit umumnya didefinisikan sebagai kristal alumina silika yang berstruktur tiga dimensi, yang terbentuk dari tetrahedral alumina dan silika dengan rongga-rongga di dalam yang berisi ion-ion logam, biasanya alkali atau alkali tanah dan molekul air yang dapat bergerak bebas. Menurut proses pembentukkannya zeolite dapat digolongkannya menjadi dua kelompok, yaitu zeolit alam dan zeolit sintesis.

Desinfeksi adalah usaha untuk mematikan mikroorganisme yang masih tersisa dalam proses, terutama ditujukan kepada mikroorganisme patogen. Proses desinfeksi dengan menggunakan ozon $\left(\mathrm{O}_{3}\right)$ berlangsung dalam tangki atau alat pencampur ozon lainnya dengan konsentrasi ozon minimal 0,1 ppm dan residu ozon sesaat setelah pengisian berkisar antara 0,06 0,1 ppm. Tindakan desinfeksi selain menggunakan ozon, dapat dilakukan dengan cara penyinaran Ultra Violet (UV) dengan panjang gelombang $254 \mathrm{~nm}$ atau kekuatan $2537^{\circ} \mathrm{A}$ dengan intensitas minimum 10.000 mw detik per $\mathrm{cm}^{2}$.

Salah satu metode pengolahan air adalah dengan penyinaran sinar ultraviolet dengan panjang gelombang pendek yang memiliki daya inti mikroba yang kuat. Cara kerjanya adalah dengan absorbsi oleh asam nukleat tanpa menyebabkan terjadinya kerusakan pada permukaan sel. Air dialirkan melalui tabung dengan lampu ultraviolet berintensitas tinggi, sehingga bakteri terbunuh oleh radiasi sinar ultraviolet, harus diperhatikan bahwa intensitas lampu ultraviolet yang dipakai harus cukup, untuk sanitasi air yang efektif diperlukan intensitas sebesar 30.000 MW sec/cm2 (Mikcro Watt per sentimeter persegi).

\section{METODE}

\section{Rancangan Penelitian}

Rancangan penelitian dalam penelitian ini dimulai dengan pengambilan sampel air baku yang diperoleh dari sumur warga di Desa Tambak Cemandi Kecamatan Sedati Kabupaten Sidoarjo. Kemudian air baku yang berwadah tandon (1) dipompa dengan pompa celup (2) dengan pipa PVC $3 / 4$ inchi yang dilengkapi dengan stop kran (3) dialirkan dan terubung dengan flow meter (4) untuk mengatur kecepatan aliran air tanah. Kemudian treatment zeolit pada tabung FRP (5), tabung ini diperuntukkan sebagai tempat media zeolit. Selanjutnya pada bagian atas terdapat sambungan pipa $3 / 4$ inchi sebagai jalur outlet air, kemudian treatment resin kation dan anion pada tabung housing (6) dan (7). Setelah itu menuju ke treatment dengan sinar UV (8). Air hasil treatment akan keluar melalui kran (9) dan 
ditampung dalam bak penampung (10).

Sebagaimana Gambar 1.

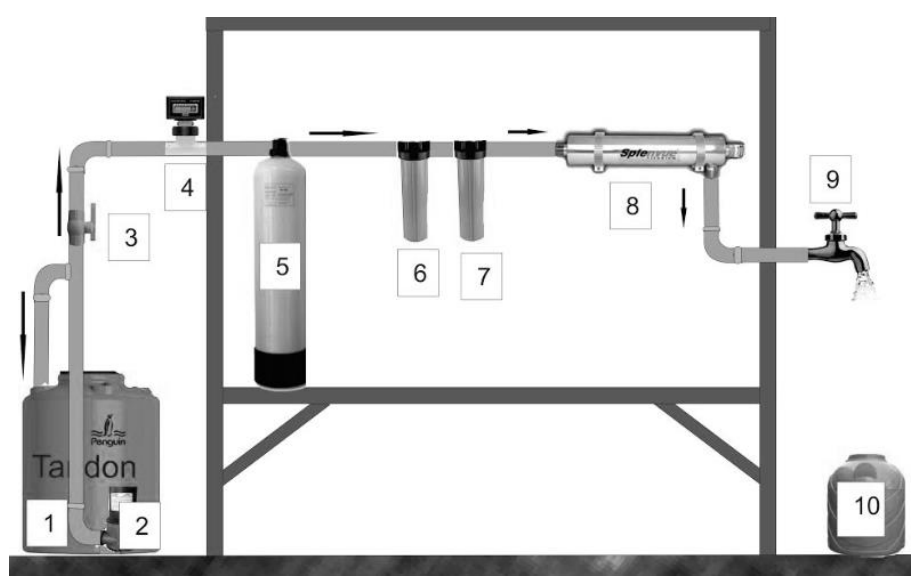

Gambar 1. Desain Instalasi Kombinasi Resin Penukar Ion, Zeolit Dan Sinar Uv.

Keterangan:

1. Tandon air baku

2. Pompa celup

3. Stop kran

4. Flow meter (pengatur laju alir)

5. Treatment zeolit pada tabung FRP

6 . Housing filter dengan media resin kation

7. Housing filter dengan media resin anion

8. Sinar UV

9. Kran air

10. Bak penampung hasil treatmennt.

Zeolit yang digunakan merupakan zeolit alam dengan ketinggian $60 \mathrm{~cm}$ yang dimasukkan di dalam tabung FRP. Perlakuan resin kation dan anion dilakukan dalam housing filter dengan ukuran 10 inchi. Sedangkan untuk sinar UV yang digunakan pada penelitian ini adalah lampu UV 39 watt dengan kapasitas 12 GPM (Galon Per Menit). Sistem aliran yang digunakan adalah sistem aliran kontinyu dengan masingmasing waktu tinggal 30 menit dan 60 menit.
Hasil perlakuan penelitian dianalisis mengacu pada para meter kadar klorida $\left(\mathrm{Cl}^{-}\right.$ ), kesadahan dan bakteri coliform (sebagaimana Tabel 1.). Selanjutnya data diolah dan disajikan dalam bentuk grafik dan prosentase, sehingga didapatkan tingkat efisiensi penurunan untuk masing-masing parameter. Perhitungan efisiensi menggunakan rumus sebagai berikut ini:

Dimana:

$$
\text { efisiensi } \%=\frac{S 0-S}{S 0} \times 100 \%
$$

S0 = kandungan parameter sebelum ditreatment

$\mathrm{S}=$ kandungan parameter setelah ditreatment. 


\section{HASIL DAN PEMBAHASAN}

\section{Hasil penelitian}

Penelitian penurunan kadar klorida $\left(\mathrm{Cl}^{-}\right)$, kesadahan, dan bakteri coliform menggunakan resin penukar ion, zeolit, dan sinar UV dilakukan di Laboratorium Rekayasa Teknik Lingkungan Universitas PGRI Adi Buana Surabaya. Sampel air baku yang digunakan adalah air tanah pada sumur gali warga di Desa Tambak Cemandi
RT/RW 09/03 Kecamatan Sedati Kabupaten Sidoarjo.

Pelaksanaan pengambilan sampel dilakukan pada tanggal 14 Mei 2019 dengan variasi waktu tinggal 30 menit dan 60 menit. Sampel tersebut diujikan di Laboratorium Uji Kualitas Lingkungan Dinas Lingkungan Hidup Provinsi Jawa Timur untuk parameter klorida $\left(\mathrm{Cl}^{-}\right)$, kesadahan dan bakteri coliform sebelum dan sesudah treatment. Data yang diperoleh disajikan dalam Tabel 1.

Tabel 1. Hasil Analisis Laboratorium Parameter Uji

\begin{tabular}{ccccccc}
\hline \multicolumn{7}{c}{ Data Kadar Klorida $\left(\mathbf{C l}^{-}\right) \mathbf{m g} / \mathbf{L}$ ( Td 30 menit ) } \\
\hline \multicolumn{7}{c}{ Waktu Pengambilan Data } \\
\hline Cl- Awal mg/L & 0 menit & $\begin{array}{c}30 \\
\text { menit }\end{array}$ & $\begin{array}{c}60 \\
\text { menit }\end{array}$ & $\begin{array}{c}90 \\
\text { menit }\end{array}$ & $\begin{array}{c}120 \\
\text { menit }\end{array}$ & $\begin{array}{c}\text { Baku } \\
\text { Mutu }\end{array}$ \\
\cline { 2 - 7 } & & 0206,7 & 2529 & 2529 & 2801,7 & 600 \\
\hline
\end{tabular}

Data Kadar Klorida $\left(\mathrm{Cl}^{-}\right) \mathrm{mg} / \mathrm{L}$ ( Td 60 menit )

\begin{tabular}{|c|c|c|c|c|c|c|}
\hline \multicolumn{7}{|c|}{ Waktu Pengambilan Data } \\
\hline $\mathrm{Cl}^{-}$Awal mg/L & 0 menit & $\begin{array}{c}60 \\
\text { menit }\end{array}$ & $\begin{array}{c}120 \\
\text { menit }\end{array}$ & $\begin{array}{c}180 \\
\text { menit }\end{array}$ & $\begin{array}{c}240 \\
\text { menit }\end{array}$ & $\begin{array}{l}\text { Baku } \\
\text { Mutu }\end{array}$ \\
\hline 3694,3 & 2578,6 & 2603,4 & 2578,6 & 2504,2 & 2057,2 & 600 \\
\hline \multicolumn{7}{|c|}{ Data Kadar Kesadahan mg/L ( Td 30 menit ) } \\
\hline \multicolumn{7}{|c|}{ Waktu Pengambilan Data } \\
\hline $\begin{array}{c}\text { Kesadahan Awal } \\
\text { mg/L }\end{array}$ & 0 menit & $\begin{array}{c}30 \\
\text { menit }\end{array}$ & $\begin{array}{c}60 \\
\text { menit }\end{array}$ & $\begin{array}{c}90 \\
\text { menit }\end{array}$ & $\begin{array}{l}120 \\
\text { menit }\end{array}$ & $\begin{array}{l}\text { Baku } \\
\text { Mutu }\end{array}$ \\
\hline 2071,5 & 1553,6 & 1722,9 & 1732,8 & 1752 & 1912,1 & 500 \\
\hline \multicolumn{7}{|c|}{ Data Kadar Kesadahan mg/L ( Td 60 menit ) } \\
\hline \multicolumn{7}{|c|}{ Waktu Pengambilan Data } \\
\hline $\begin{array}{c}\text { Kesadahan Awal } \\
\text { mg/L }\end{array}$ & 0 menit & $\begin{array}{c}60 \\
\text { menit }\end{array}$ & $\begin{array}{c}120 \\
\text { menit }\end{array}$ & $\begin{array}{c}180 \\
\text { menit }\end{array}$ & $\begin{array}{l}240 \\
\text { menit }\end{array}$ & $\begin{array}{l}\text { Baku } \\
\text { Mutu }\end{array}$ \\
\hline 2071,5 & 1732,8 & 1673,1 & 1673,1 & 1633,3 & 1394,2 & 500 \\
\hline
\end{tabular}


Data Kadar Bakteri Coliform MPN/100ml ( Td 30 menit )

\begin{tabular}{ccccccc}
\hline \multicolumn{7}{c}{ Waktu Pengambilan Data } \\
\hline $\begin{array}{c}\text { Bakteri Coliform } \\
\text { Awal } \\
\text { MPN/100ml }\end{array}$ & 0 menit & $\begin{array}{c}30 \\
\text { menit }\end{array}$ & $\begin{array}{c}60 \\
\text { menit }\end{array}$ & $\begin{array}{c}90 \\
\text { menit }\end{array}$ & $\begin{array}{c}120 \\
\text { menit }\end{array}$ & $\begin{array}{c}\text { Baku } \\
\text { Mutu }\end{array}$ \\
\cline { 2 - 6 } 7100 & 160 & 60 & 340 & 220 & 60 & 50 \\
\hline \multicolumn{7}{c}{ Waktu Pengambilan Data } \\
\hline \multicolumn{7}{c}{$\begin{array}{c}120 \\
\text { Data Kadar Bakteri Coliform MPN/100ml ( Td 60 menit ) }\end{array}$} \\
$\begin{array}{c}\text { MPN/100ml } \\
\text { Bakteri Coliform }\end{array}$ \\
\cline { 2 - 7 } 7100
\end{tabular}

\section{Pembahasan}

Adanya beda penurunan nilai menunjukkan tingkat efisiensi penurunan kadar klorida $\left(\mathrm{Cl}^{-}\right)$, kesadahan dan bakteri coliform. Perhitungan efisiensi penurunan disajikan dalam bentuk prosentase (\%) dan dijabarkan berdasarkan masing-masing parameter yang diujikan.

\section{Tentang Penurunan Klorida $\left(\mathrm{Cl}^{-}\right)$}

Perbedaan efisiensi pengolahan pada variasi waktu tinggal 30 menit dan 60 menit dijabarkan dalam bentuk tabel dan grafik. Berikut hasil analisis efisiensi kadar klorida $\left(\mathrm{Cl}^{-}\right)$untuk masing-masing variasi waktu tinggal disajikan dalam Tabel 3 dan Tabel 4.

Tabel 2. Efisiensi Kadar Klorida (Cl-) ( Td 30 menit)

\begin{tabular}{ccc} 
Waktu Pengambilan data & $\begin{array}{c}\text { Kadar Klorida }\left(\mathrm{Cl}^{-}\right) \\
(\mathrm{mg} / \mathrm{L})\end{array}$ & Efisiensi (\%) \\
\hline Awal & 3694,3 & \\
0 & 2033,1 & 45 \\
30 & 2206,7 & 40,3 \\
\hline 60 & 2529 & 31,5 \\
90 & 2529 & 31,5 \\
120 & 2801,7 & 24,2 \\
\hline
\end{tabular}


Tabel 3. Efisiensi Kadar Klorida (Cl-) ( Td 60 menit)

\begin{tabular}{ccc}
\hline Waktu Pengambilan data & $\begin{array}{c}\text { Kadar Klorida }\left(\mathrm{Cl}^{-}\right) \\
(\mathrm{mg} / \mathrm{L})\end{array}$ & Efisiensi (\%) \\
\hline Awal & 3694,3 & \\
0 & 2578,6 & 30,2 \\
60 & 2603,4 & 29,5 \\
120 & 2578,6 & 30,2 \\
180 & 2504,2 & 32,2 \\
240 & 2057,9 & 44,3 \\
\hline
\end{tabular}

Berdasarkan Tabel 2 dan Tabel 3 menunjukkan terjadinya efisiensi penurunan kadar klorida $\left(\mathrm{Cl}^{-}\right)$setelah perlakuan dengan waktu tinggal 30 menit dan 60 menit. Pada waktu tinggal 30 menit prosentase nilai penurunan terendah adalah $24,2 \%$ dan yang tertinggi $45 \%$. Sedangkan pada waktu tinggal 60 menit prosentase hasil penurunan terendah adalah $29,5 \%$ dan yang tertinggi $44,3 \%$.

Berdasarkan Tabel 2 dan Tabel 3 dapat dilihat bahwa penurunan kadar klorida $\left(\mathrm{Cl}^{-}\right)$tertinggi pada kedua waktu tinggal yaitu pada menit ke 30 dengan waktu pengambilan data menit ke 0 dan kemudian naik kembali. Hal ini dimungkinkan karena penggunaan resin anion tunggal yang menyebabkan anion $\left(\mathrm{Cl}^{-}\right)$yang ada pada resin terserap ke air, sehingga keadaan ini mampu meningkatkan kadar klorida $\left(\mathrm{Cl}^{-}\right)$di dalam air. Dibandingkan dengan penelitian yang dilakukan Purwoto, S. (2009) tentang desalinasi air payau secara ion exchange dengan treatment resin sintesis mampu meremoval kandungan salinitas sebagai berikut, prosentasi removal untuk kadar $\left(\mathrm{Cl}^{-}\right.$ ) dengan media pasangan resin kation-anion sebesar 44,4 \% dengan konsentrasi awal salinitas sebesar $1011 \mathrm{ppm}$, sedangkan untuk konsentrasi awal salinitas sebesar 4046 ppm diperoleh prosentasi removal sebesar 12,8 $\%$. Hasil treatment untuk parameter klorida $\left(\mathrm{Cl}^{-}\right)$pada waktu tinggal 30 menit dan 60 menit cukup efektif, namun masih belum memenuhi Baku Mutu klorida sesuai Peraturan Menteri Kesehatan Republik Indonesia Nomor 32 Tahun 2017 untuk keperluan higiene sanitasi sebesar $600 \mathrm{mg} / \mathrm{L}$.

\section{Tentang Penurunan Kesadahan}

Perbedaan efisiensi pengolahan pada variasi waktu tinggal 30 menit dan 60 menit dijabarkan dalam bentuk tabel dan grafik. Berikut hasil analisis efisiensi kadar kesadahan untuk masing-masing variasi waktu tinggal disajikan dalam Tabel 4 dan Tabel 5.

Tabel 4. Efisiensi Kadar Kesadahan ( Td 30 menit)

\begin{tabular}{ccc}
\hline Waktu Pengambilan data & Kadar Kesadahan(mg/L) & Efisiensi (\%) \\
& & \\
\hline Awal & 2071,5 & - \\
0 & 1553,6 & 25 \\
30 & 1772,9 & 16,8 \\
60 & 1732,8 & 16,4 \\
90 & 1752 & 15,4 \\
120 & 1912,1 & 7,7 \\
\hline
\end{tabular}


Tabel 5. Efisiensi Kadar Kesadahan ( Td 60 menit)

\begin{tabular}{ccc}
\hline Waktu Pengambilan data & Kadar Kesadahan(mg/L) & Efisiensi (\%) \\
\hline Awal & 2071,5 & - \\
0 & 1732,8 & 16,4 \\
60 & 1673,1 & 19,2 \\
120 & 1673,1 & 19,2 \\
180 & 1633,3 & 21,2 \\
240 & 1394,2 & 32,7 \\
\hline
\end{tabular}

Berdasarkan Tabel 4 dan Tabel 5 menunjukkan terjadinya efisiensi penurunan kadar kesadahan setelah perlakuan dengan waktu tinggal 30 menit dan 60 menit. Pada waktu tinggal 30 menit prosentase nilai penurunan terendah adalah $7,7 \%$ dan yang tertinggi 25\%. Sedangkan pada waktu tinggal 60 menit prosentase hasil penurunan terendah adalah $16,4 \%$ dan yang tertinggi $32,7 \%$.

Berdasarkan Tabel 4 dan Tabel 5 dapat dilihat bahwa penurunan kadar kesadahan terbesar pada kedua waktu tinggal yaitu pada menit ke 60 dengan waktu pengambilan data menit ke 240. Nilai kesadahan total pada media zeolit yang meningkat dapat disebabkan media zeolit yang digunakan adalah zeolit alam yang umumnya terdapat dalam bentuk campuran dengan senyawa atau unsur pengotor dalam jumlah tertentu. Pengotor tersebut berupa $\mathrm{Ca}, \mathrm{Mg}, \mathrm{Fe}$ yang juga dapat menyebabkan peningkatan kesadahan (Lestari D.Y 2010).

Penurunan kadar kesadahan ini ini serupa dengan penelitian Purwoto, S. (2010), treatment zeolit yang dijalankan dengan sistem aliran up-flow menggunakan time detention (td) 30 menit, kedalaman zeolit $60 \mathrm{~cm}$ dengan tujuan reduksi parameter air bersih didapatkan remove capacity: kesadahan total $185.72 \mathrm{ppm}$, kalsiurn 100 ppm, magnesium 85.72 ppm, silika $25 \mathrm{ppm}$, klorida $52 \mathrm{ppm}$, zat padat terlarut (TDS) $311 \mathrm{ppm}$, besi $1.41 \mathrm{ppm}$, mangan $0.46 \mathrm{ppm}$. Hasil treatment untuk parameter kesadahan pada waktu tinggal 30 menit dan 60 menit cukup efektif, namun masih belum memenuhi Baku Mutu klorida sesuai Peraturan Menteri Kesehatan Republik Indonesia Nomor 32 Tahun 2017 untuk keperluan higiene sanitasi sebesar 500 $\mathrm{mg} / \mathrm{L}$.

\section{Tentang Penurunan Bakteri Coliform}

Perbedaan efisiensi pengolahan pada variasi waktu tinggal 30 menit dan 60 menit dijabarkan dalam bentuk tabel dan grafik. Berikut hasil analisis efisiensi kandungan bakteri coliform untuk masingmasing variasi waktu tinggal disajikan dalam Tabel 6 dan Tabel 7.

Tabel 6. Efisiensi Kandungan Bakteri coliform ( Td 30 menit) Waktu Pengambilan
data
Kandungan Bakteri Coliform
(MPN/100ml)
Efisiensi

(\%)

\begin{tabular}{ccc}
\hline Awal & 7100 & \\
0 & 160 & 97,7 \\
30 & 60 & 99,2 \\
60 & 340 & 95,2 \\
90 & 220 & 96,9 \\
120 & 60 & 99,2 \\
\hline
\end{tabular}


Tabel 7. Efisiensi Kandungan Bakteri coliform ( Td 60 menit)

\begin{tabular}{ccc}
\hline Waktu Pengambilan data & $\begin{array}{c}\text { Kandungan Bakteri Coliform } \\
\text { (MPN/100ml) }\end{array}$ & Efisiensi (\%) \\
\hline Awal & 7100 & \\
0 & 200 & 97,2 \\
60 & 120 & 98,3 \\
120 & 60 & 99,2 \\
180 & 100 & 98,6 \\
240 & 60 & 99,2 \\
\hline
\end{tabular}

Berdasarkan Tabel 6 dan Tabel 7 menunjukkan terjadinya penurunan kandungan bakteri coliform setelah perlakuan pada waktu tinggal 30 menit dan 60 menit. Pada waktu tinggal 30 menit prosentase nilai penurunan terendah adalah $95,2 \%$ dan yang tertinggi 99,2 \%. Sedangkan pada waktu tinggal 60 menit prosentase hasil penurunan terendah adalah $97,2 \%$ dan yang tertinggi 99,2 \%. Berdasarkan Tabel 6 dan Tabel 7 dapat dilihat bahwa penurunan kandungan bakteri coliform tertinggi pada kedua waktu tinggal yaitu pada menit ke 30 dan menit ke 60 dengan waktu pengambilan data menit ke 120 menit dan 240 menit.

Hasil yang diperoleh dari treatment terlihat sangat signifikan dalam menurunkan kandungan bakteri coliform pada air baku. Perbedaan hasil pengolahan pada penelitian ini dapat disebabkan oleh senyawa organik dan material tersuspensi yang ada dalam air, sehingga menurunkan kinerja pengolahan pada sinar UV. Penelitian ini sejalan dengan yang dilakukan (Syarifudin A et al. 2014) tentang efektivitas "portable $U V$ disinfection" dalam menurunkan E. coli pada air minum menunjukkan bahwa UV dapat menurunkan jumlah bakteri $E$. coli prosentasi penurunan mencapai 98,3\% dengan waktu detensi (contact time) UV terhadap air secara optimal 20 menit dan ketebalan air yang tepat $10 \mathrm{~cm}$.

Hal ini dikarenakan air yang terkena radiasi sinar UV maka akan semakin besar pula tingkat kerusakan sel mikroorganisme. Pernyataan ini diperkuat oleh Cahyonugroho (2010) bahwa semakin lama pemaparan lampu UV yang diberikan pada kedalaman sampel yang rendah, maka reduksi mikroorganisme akan semakin besar pula. Lama penyinaran dipengaruhi oleh debit aliran, luas penampang dan panjang selang. Hasil treatment untuk parameter bakteri coliform pada waktu tinggal 30 menit dan 60 menit sangat efektif, namun masih belum memenuhi Baku Mutu klorida sesuai Peraturan Menteri Kesehatan Republik Indonesia Nomor 32 Tahun 2017 untuk keperluan higiene sanitasi sebesar 50 MPN/100ml.

\section{KESIMPULAN}

Kesimpulan dari penelitian ini adalah adanya penurunan kadar klorida $\left(\mathrm{Cl}^{-}\right)$, kadar kesadahan, dan kandungan bakteri coliform setelah treatment tertinggi pada waktu tinggal 30 menit dan 60 menit yang telah dilakukan didapatkan hasil masing-masing 2033,1 mg/L, 1394,2 mg/L, dan 60 MPN/100ml. Konsentrasi kadar tersebut belum memenuhi baku mutu air bersih PERMENKES 32/2017. Efisiensi treatment yang telah dilakukan mampu menurunkan kadar klorida $\left(\mathrm{Cl}^{-}\right)$sebesar $45 \%$, kadar kesadahan 32,7 \% dan kandungan bakteri coliform hingga 99,2\%.

\section{UCAPAN TERIMA KASIH}

Ucapan terima kasih disampaikan kepada kepala Laboratorium Teknik Lingkungan yang telah memberikan bantuan alat dan bahan untuk penelitian, temanteman seperjuangan yang telah membantu menyelesaikan penelitian ini dan kepada seluruh staf pengajar Program Studi Teknik Lingkungan Universitas PGRI Adi Buana Surabaya yang telah mendukung dan memberikan pengarahan demi terselesainya penelitian ini. 


\section{DAFTAR PUSTAKA}

Atmoko,R.D. (2012), "Pemanfaatan Karbon Aktif BatuBara Termodifikasi TiO2 Pada Proses Reduksi Gas Karbon Monoksida(CO) Dan Penjernihan Asap Kebakaran”. Penerbit FT UI,Jakarta.

Cahyonugroho, O.K. (2010), "Pengaruh Intensitas Sinar Ultraviolet dan Pengadukan Terhadap Reduksi Jumlah Bakteri E.coli” Jurnal Ilmiah Teknik Lingkungan. 2(1):18-23.

Eukene,Bensig., Flores, Mary Joyce \& Maglangit, Fleurdelis. (2014), "Water Quality Asessment of Bulacao River, Cebu, Philipphines Using Fecal and Total Coliform as Indicator" Journal of Biodiversity and Environmental Science (JBES), 5(1), 470-475.

Lestari, D. Y. (2010), "Kajian modifikasi dan karakterisasi zeolit alam dari berbagai Negara" Prosiding seminar nasional Kimia dan Pendidikan Kimia.

Nugroho, Wahyu., Purwoto, Setyo. (2013), "Pengolahan Air Tanah Berbasis Treatment Ferrolite, Manganese Zeolite Removal Klorida, Tds Dan Besi Pada Air Payau Melalui Penukar Ion dan Filtrasi Campuran Zeolit Aktif Dengan Karbon Aktif , dan Ion Exchange" JURNAL WAKTU ; ISSN : 1412-1867 Vol.11 (01), 47-59.

Nurhayati, I., \& Purwoto, S. (2014), "The Combination of Coagulant Aid, Ion Exchanger, and Reverse Osmosis (RO ) on Brackish Water Treatment" Journal of Natural Sciences Research 4(24), 26-30.

Prayitno, Agus. (2009), "Uji bakteriologi air baku dan air siap konsumsi dari PDAM Surakarta ditinjau dari jumlah bakteri Coliform" Laporan penelitian. Universitas Muhammadiyah Surakarta Fakultas Kegurun dan Ilmu Pendidikan. Surakarta: Universitas Muhamadiyah Surakarta.

Purwoto, Setyo. (2009), "Desalinasi Ir Payau Secara Ion Exchange dengan Treatment Resin Sintesis" Jurnal Teknik "WAKTU” 7(01), 52-59.

Purwoto, Setyo. (2010), "Remove Capacity Treatment Zeolit Untuk Parameter Air Bersih" WAHANA ; ISSN : 0853-4403, ed. Agustus 2010 55(2): 63-70.

Rahmawati dan Nurhayati. (2013), "Pengaruh Jenis Media Filtrasi Kualitas Air Sumur Gali" Jurnal Teknik Waktu Volume 14 Nomor 02 - Juli 2016 - ISSN : 1412-1867.

Rakkito dan Surya. (2015), "Penyisihan E.Coli Air Sumur Menggunakan Radiasi Sinar Ultra Violet" Jurnal Ilmiah Teknik Lingkungan Vol.7 No.2.

Supardi. (2009), "Pelunakan Air Sadah dengan Menggunakan Zeolit Sintesis".Bandung. Institut Teknologi Bandung.

Syarifudin A, et al. (2014), "Efektivitas "Portable UV Disinfection" Jurnal Kesehatan Lingkungan Vol. 11 No.2 Juli 2014.

Ulfin, Ita. (2013). "Penukar Ion”. Surabaya: Institut Teknologi Surabaya 